\title{
The Antecedents and Consequence of Supplier Unethical Behaviour in Buyer-Supplier Relationship in Tanzania: Testing using the PLS Approach
}

\author{
Catholic Sumuni \\ Institute of Accountancy, Arusha, P.O. Box 2798, Arusha, Tanzania
}

\begin{abstract}
Using social exchange theory, this paper investigates the antecedents of supplier unethical practices on continuity of buyer-supplier relation and its consequence on firm performance. The analysis of 130 informants from public entities in Tanzania, the results indicates that two supplier's unethical practices have significant impact on the continuity of buyer-supplier relation which include corruption and supplier deceitful. Using the mediating role continuity of buyer-supplier relationship, the study indicates that corruption and deceitful affect the firm performance (quality and delivery). The research conclude that the public entities should be very careful on the effects of unethical practices on continuity of relationship and managers in public organizations should not take for granted particularly the corruption practices and deceitful. This study provides insightful contribution to practitioners and researchers intended to conducted research on ethical supply chain.
\end{abstract}

Keywords: Unethical behaviour; Opportunism; Corruption; Deceitful; Buyer-supplier

DOI: $10.7176 / \mathrm{JESD} / 13-2-06$

Publication date: January $31^{\text {st }} 2022$

\section{Introduction}

The continuity and success of buyer-supplier relationship depends mainly on the ethical practices of both partners in the relationship. The ethical practices are viewed as the critical facet of cooperative environment in business operations (Luo et al., 2015; Shamsollahi et al., 2020). Supplier is vital partner that ensure availability of supplies to the organization at the right time, in right quality, quantity and cost. However, over the past decades, the unethical practices from suppliers has increased gradually due numerous factors that affect the longevity of the relationship in continuum. Jamil et al. (2019) highlighted the antecedent that triggered such behaviour including the overdependence of buyer on suppliers, sole-source relationship and little benefits of the suppliers in the contracts. Hawkins et al. (2008) revealed that opportunism as the main antecedent of unethical practices from suppliers that emerged due to lack information sharing between the two sides. Supplier opportunism is defined as supplier self-interest-seeking behavior with guile, is a potential concern for a supplier-buyer relationship (Skowronski et al., 2020). The consequence of supplier opportunism includes the risk of shirking responsibilities by suppliers, providing false information, making hollow promises to buyer and loosing of confidential information to competitors (Yan and Kull, 2015).

The competitive environment and scarcity of supplies in the market with regard to all sectors, lures suppliers to perform unethical maneuvers influenced by other paid competitors that jeopardize their commercial relations (Ahamed et al., 2020; Wang et al., 2014). Accordingly, when unethical emerged, the trust between parties is betrayed, conflicts arise, and relations become strained. Williamson (1985) argue that prevention of opportunistic and unethical behaviors is through fair implementation (win-win) situation between the parties and enforce the relationship through having legal contracts and terms. Despite the existence of the problem, in Tanzania, research that examine the magnitude of unethical practices is still at low pace. According Mazibuko and Fourie (2017), the problem of unethical practices from suppliers in developing countries is very acute and have detrimental impact to the service delivery in public entities while enforcement has not play a successful role. The most citied behaviour on unethical practices of supplier in developing countries include providing low quality service, corruption and greed of money. Appolloni and Nshombo (2014) revealed that supplier in Sub-Sahara African collides with other corrupt officers and led to dominant problems in service delivery and public infrastructures as a resultant problem. The objective of this study, therefore is to illuminate how deceitful, opportunism and corruption may affect the continuity of buyer-supplier relationship and performance of public entities. Therefore, the study examines contextual antecedents, performance consequences, and mediating influence of buyer-supplier relationship to firm performance in public entities in Tanzania.

\subsection{Literature Review}

\subsection{Supply Chain Ethics}

Our business world is faced with profound moral crisis that what was treasured in the past as truths are now regarded as myths or outright conservatism or relativism. When truths are challenged and rationalized in many ways, ethical values become a riskier subject to deal with (Svensson and Bååth, 2008). The ethical issues in supply 
chain has risen alarming attention to both practitioners and researchers with respect to continuity of relationships and business implementation. As the goal of supply chain is to ensure smooth flow of components and product along the chain, thus any ethical issues that might disrupt the flow of materials are taken very serious by organizations. Supply chain ethics refers to the process of ensuring effective flow of materials, components and products while subscribing to an ethical code (Gonzalez-Padron, 2016). Ethical thought in supply chain started on the lower level of individual employee and higher level at organization level (Kaynak et al., 2015).

Recently, unethical practices have penetrated much in private and public organization led to damage on service distributions. The ethical problem confronted frequently in supply chain involved buyer and suppliers (Yun et al., 2019). However, in this study the focus is the unethical behaviour emanated from supplier side. The upstream side is very important part of supply chain spectrum and any problem that arise can jeopardize the entire supply chain because the supply chain nodes are dependent. Therefore, the problem propagates from one node to another node and affect the entire chain. Ideally, the primary concern of ethical discussions are the results of the behaviors that intentionally or unintentionally led to bending of laws, ethical principles and code of conduct in organization (Bag et al., 2018).

\subsection{Supplier Unethical Behaviors}

Supplier unethical behaviour is widely discussed in past literatures (Chen and Baddam, 2015). The supplier unethical behaviour can emerged from him/her select or being influenced by the buyer employees whom they are working with him to behave in such manner. The tendency toward supplier unethical behaviors depend on other factors such as loophole of weak ethical principles that governed entities, imperfect moral values and market culture in which the supplier operate. More important, buyer have influence on the behaviour of his/her supplier. Unethical practices of supplier can be in different form such as outright fraud: opportunism, deceitful, unfair competition and communication, non-respect of agreements etc. (Carter, 2000). As many literatures have discussed forms of supplier unethical practices, in this study, three types were discussed including opportunism, deceitful and corruption.

Supplier opportunism refers to the behaviour of taking advantage on something with little regard to ethical principles or with what the consequences are for the buyer (Wang et al., 2016). Opportunistic behaviour is recognized as the form of fraud that the supplier takes over his/her buyer in business transactions (Wang et al., 2014). Williamson (1995) also introduced the concept of opportunism in transaction cost economics theory as the self-interest seeking with guile (Williamson, 1993). Williamson (1995) suggest the best mechanism that can prevent the opportunism behaviour including having legal contracts with suppliers and regulations that abide both partners in the contract. According to Rebernik and Bradač (2006) in one off contract the supplier is likely to behave opportunistic compares to long term contract which are governed by legal procedures. There are several reasons that have been viewed as the common cause of supplier opportunism including lack of information sharing, having win-lose situation where the supplier bares more cost that benefits compared to his counterpart and trust between the two side in business transactions. Ozkan-Tektas (2014) argue that the more the supplier become opportunistic the more the riskier on the continuity of buyer-supplier relationship. This is the argument that have been widely believed by scholars in supply chain ethics (Hawkins et al., 2008; Tangpong et al., 2010; Wang et al., 2013). Therefore, based on the above discussion the researcher proposed that:

H1a. Opportunism is likely to affect the continuity of buyer-supplier relationship.

Supplier deceitful refers to the practices of supplier behave in a dishonest way by making the buyer believe something that is not true (Kaynak et al., 2015). The deceitful practices relate to activities purposely misleading the buyer concerning the business transactions. Literature has categorized four types of deceitful including the low relational risk, short deceit horizon (type one); high relational risk, short deceit horizon (type two); low relational risk, long deceit horizon (type three); and high relational risk, long deceit horizon (type four) (Das, 2005). Although it is not a common practice tested in past literature, but some research indicates that deceitful implementations of the supplier adversely affect the satisfaction level of the buyer and vice versa (Das, 2005). Kaynak et al. (2015) argued that when the supplier is deceitful it tends to affect the relationship with the buyer and the continuity of the relationship will be at risk. Therefore, based on the above discussion the researcher proposed that:

H1b. Deceitful is likely to affect the continuity of buyer-supplier relationship.

Corruption can be defined as the bribery and the acceptance of bribes as well as granting and accepting undue advantages with common offences including blackmail, fraud, embezzlement, and document forgery (de Sousa Monteiro et al., 2018). In emerging market, a supplier bribes employees of the procurement department in order to obtain a contract is a common unethical practice (Millington et al., 2005). Bendixen and Abratt (2007), if a supplier bribes employee from public entities related to procurement, there is a big chance that the employees will influence the procurement proceeding in favor of the supplier which led a huge consequence on the quality, delivery and cost. On the other side, the corruption behaviour might undermine the continuity of the buyer-supplier relationship especially when the unethical practices are known by the buyer management team (Millington et al., 2005). Therefore, based on the above discussion the researcher proposed that: 


\section{H1c. Corruption is likely to affect the continuity of buyer-supplier relationship.}

\subsection{Mediating role of continuity relationship}

The continuity of buyer-supplier relationship act as a bridge for the organization to achieve the performance (Narain and Singh, 2012). When the organization have effective long term relationship between buyer and supplier, there is a possibility for the organization to succeed in terms of performance. Kaynak et al. (2015) posit that continuity of the relationship between the supplier and buyer build a bond between them. In one way the supplier feels to be part of the organization and foster the performance in the organization and vice versa is true. In that way, the researcher believe that continuity of relationship can mediate the effect from supplier unethical practices to organization performance specifically quality and delivery performance. This is to say, when the continuity is affected the consequences is on the organization performance (Mugarura et al., 2010). Therefore, based on the above discussion the researcher proposed that:

H2a. Continuity of buyer-supplier relationship mediate the effect between opportunism and quality performance. $H 2 b$. Continuity of buyer-supplier relationship mediate the effect between opportunism and delivery performance. H3a. Continuity of buyer-supplier relationship mediate the effect between deceitful and quality performance. $H 3 b$. Continuity of buyer-supplier relationship mediate the effect between deceitful and delivery performance. $\mathrm{H4a}$. Continuity of buyer-supplier relationship mediate the effect between corruption and quality performance. $H 4 b$. Continuity of buyer-supplier relationship mediate the effect between corruption and delivery performance.

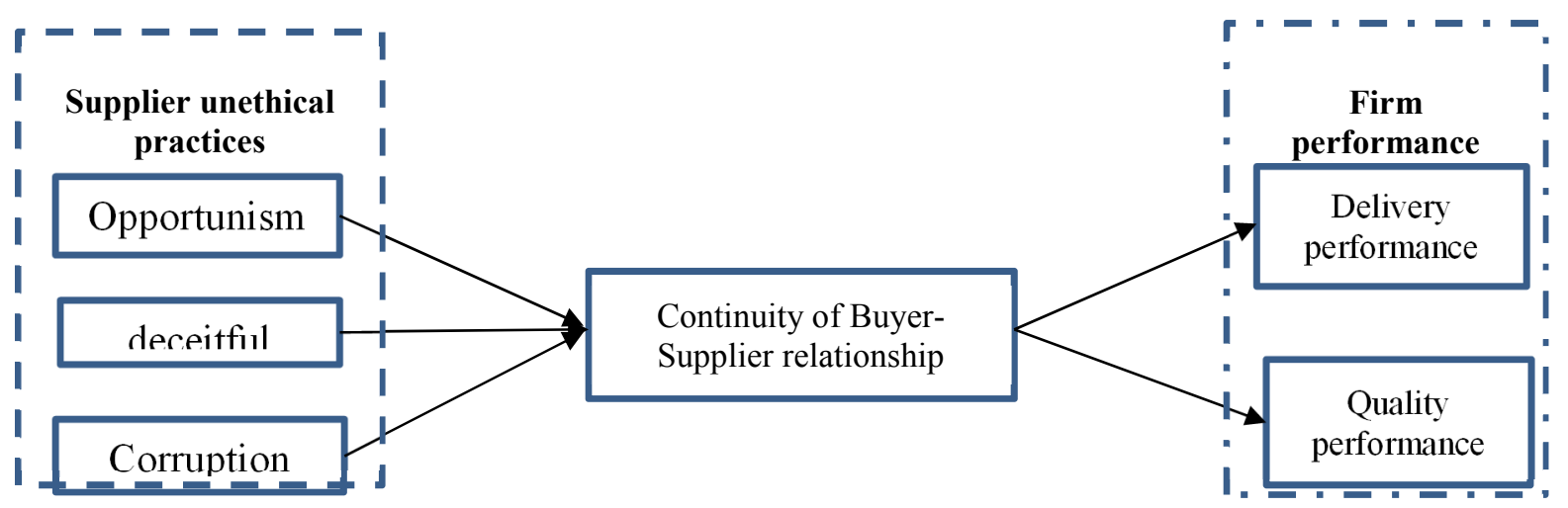

Fig. 1. Conceptual model.

\section{Research methodology}

\subsection{Measures}

The multi-item scales of the construct were based on previous literatures in order to test the identified hypotheses. All the items of five contract was measured by means of a 5-point Likert scale manner of "1"- strongly disagree to " 5 "- strongly agree. All items presented in questionnaire for this study was those taken from other studies and that have been tested its reliability and validity. The unethical behaviors of the supplier are composed of three aspects: deceitful, opportunism and corruption. The three variables making a total of ten (10) items in the following manner: Three (3) items for deceitful, four (4) items for opportunism and three (3) items for corruption all adopted from Luo et al. (2015). The continuity of Buyer-Supplier relationship consists of four (4) items all measure to what extent the unethical behaviour affect the longevity of the relationship between buyer and supplier. All four (4) items were adopted from Luo et al. (2015). Finally, the firm performance consists of two (2) variables. All two (2) variables were extracted from Corsten et al. (2011). The quality performance and delivery performance have three (3) items each making a total of six (6) items. In this study, the unethical practices are categorized at antecedents of buyer-supplier relationship and firm performance as the consequence of buyer - supplier relationship.

\subsection{Sample and data collection}

The sample was collected from public sectors employees randomly from public entities in Tanzania. The researcher designed the questionnaire in English targeting the employees in different sections of public entities particularly in procurement management unit, tender board members, finance units and user departments. The data were collected between in 2020 whereas the questionnaires was designed in electronic form and distributed through common social media and email of some public organizations. After five (5) months of distribution of the questionnaires to 500 number of informants, a total of 130 respondents submitted a response through online system making a total response rate of $26.0 \%$ (Table 1 ). The common method bias (CMB) was used as a source of 
measurement error. The Harman's single-factor test was employed to test the common method bias. The results of this test demonstrated that neither a single factor emerged nor did one general factor present itself when considering all variables at once in an un-rotated exploratory factor analysis (EFA). As such, there is no reason to believe that CBM was problematic to our analysis (Chin et al., 2012).

Table1. Sample characteristics

\begin{tabular}{|l|l|l|}
\hline \multicolumn{2}{|l|}{ Sample } & \multicolumn{2}{l|}{ Percentage (\%) } \\
\hline Description & \multicolumn{2}{l|}{} \\
\hline Male (1) & 92 & $70 \%$ \\
\hline Female (2) & 38 & $30 \%$ \\
\hline Nature of firm & \multicolumn{2}{l|}{} \\
\hline Parastatal organization & 37 & $28.5 \%$ \\
\hline Local government Authorizes (LGAs) & 46 & $35.4 \%$ \\
\hline Ministry & 47 & $36.2 \%$ \\
\hline Job title & \multicolumn{2}{l|}{} \\
\hline Procurement officer & 39 & $30 \%$ \\
\hline Tender Board member & 20 & $15.4 \%$ \\
\hline Other & 71 & $54.6 \%$ \\
\hline Region & \multicolumn{2}{|l|}{} \\
\hline Morogoro & 24 & $18.5 \%$ \\
\hline Arusha & 27 & $20.7 \%$ \\
\hline Dar es salaam & 30 & $23.1 \%$ \\
\hline Mbeya & 12 & $9.2 \%$ \\
\hline Moshi & 30 & $23.1 \%$ \\
\hline Other & 07 & $5.4 \%$ \\
\hline
\end{tabular}

\section{Analysis}

\subsection{Reliability and validity}

In determination of reliability and validity of scales used in this study, three common methods were used in this study. a Cronbach alpha, composite reliability (CR) and the average variance extracted (AVE) were utilized. Ideally, the internal consistency is demonstrated when the reliability of each measure in a scale is above 0.60 (Kline, 2015). The Cronbach's $\alpha$ and composite reliability values explain over the threshold value of 0.60 , as recommended by Hair et al. (2006) Therefore, on the aspect of reliability all items have proved to have adequate internal consistency. The study determines, the convergent validity using the threshold of 0.50 of AVE. In this study, AVE measures are above the cut-off of 0.50 for all constructs (Fornell and Larcker, 1981). The factor scores, Cronbach alpha, composite reliability and AVE results are shown in Table 2.

Table 2. Factor loading, Reliability, AVE and Composite reliability

\begin{tabular}{|c|c|c|c|c|c|}
\hline Composite variable & Items & Factor loading & $\begin{array}{l}\text { Reliability } \\
(\alpha)\end{array}$ & $\begin{array}{l}\text { Average Variance } \\
\text { Expected (AVE) }\end{array}$ & $\begin{array}{c}\text { Composite reliability } \\
(\mathrm{CR})\end{array}$ \\
\hline \multirow{4}{*}{$\begin{array}{l}\text { Continuity of Buyer- } \\
\text { Supplier relationship }\end{array}$} & CBSR1 & 0.816 & \multirow[t]{4}{*}{0.897} & \multirow[t]{4}{*}{0.7541} & \multirow[t]{4}{*}{0.9238} \\
\hline & CBSR2 & 0.732 & & & \\
\hline & CBSR3 & 0.961 & & & \\
\hline & CBSR4 & 0.944 & & & \\
\hline \multirow[t]{3}{*}{ Corruption } & COR1 & 0.700 & \multirow[t]{3}{*}{0.87} & \multirow[t]{3}{*}{0.500} & \multirow[t]{3}{*}{0.7489} \\
\hline & COR2 & 0.667 & & & \\
\hline & COR3 & 0.750 & & & \\
\hline \multirow[t]{3}{*}{ deceitful } & DEC1 & 0.959 & \multirow[t]{3}{*}{0.680} & \multirow[t]{3}{*}{0.7693} & \multirow[t]{3}{*}{0.9074} \\
\hline & DEC2 & 0.690 & & & \\
\hline & DEC3 & 0.955 & & & \\
\hline \multirow[t]{3}{*}{ Opportunism } & OPP2 & 0.750 & \multirow[t]{3}{*}{0.79} & \multirow[t]{3}{*}{0.5678} & \multirow[t]{3}{*}{0.7892} \\
\hline & OPP3 & 0.520 & & & \\
\hline & OPP1 & 0.933 & & & \\
\hline \multirow[t]{3}{*}{ Delivery performance } & DP2 & 0.769 & \multirow[t]{3}{*}{0.826} & \multirow[t]{3}{*}{0.5648} & \multirow[t]{3}{*}{0.7955} \\
\hline & DP3 & 0.730 & & & \\
\hline & DP1 & 0.909 & & & \\
\hline \multirow[t]{3}{*}{ Quality performance } & QP1 & 0.840 & \multirow[t]{3}{*}{0.755} & \multirow[t]{3}{*}{0.7427} & \multirow[t]{3}{*}{0.8965} \\
\hline & QP2 & 0.868 & & & \\
\hline & QP3 & 0.877 & & & \\
\hline
\end{tabular}




\subsection{Structural model PLS}

The Partial Least Squares (PLS) is an approach used in multivariate statistics used to test the casual relationship when the study used small sample size (Hair et al., 2013; Hair Jr et al., 2014). PLS is viewed as the most powerful tool for analyzing the structural equation modeling (SEM), because it can display the skewed distribution among small-scale samples, and it can determine the relations kept in the background due to multicollinearity problems and measurement errors. Principally, PLS combines the principal components analysis (PCA) and multivariate regression in order to assess the relationship of variables included in the model. Using a bootstrap method of default (1000), the Partial Least Squares was analyzed using the SMART PLS3.0 software (Sarstedt and Cheah, 2019; Wong, 2013). In this study, the effect of deceitful, opportunism and corruption as antecedents was tested against the mediating variable of buyer-supplier relationship and outcome variable of firm performance.

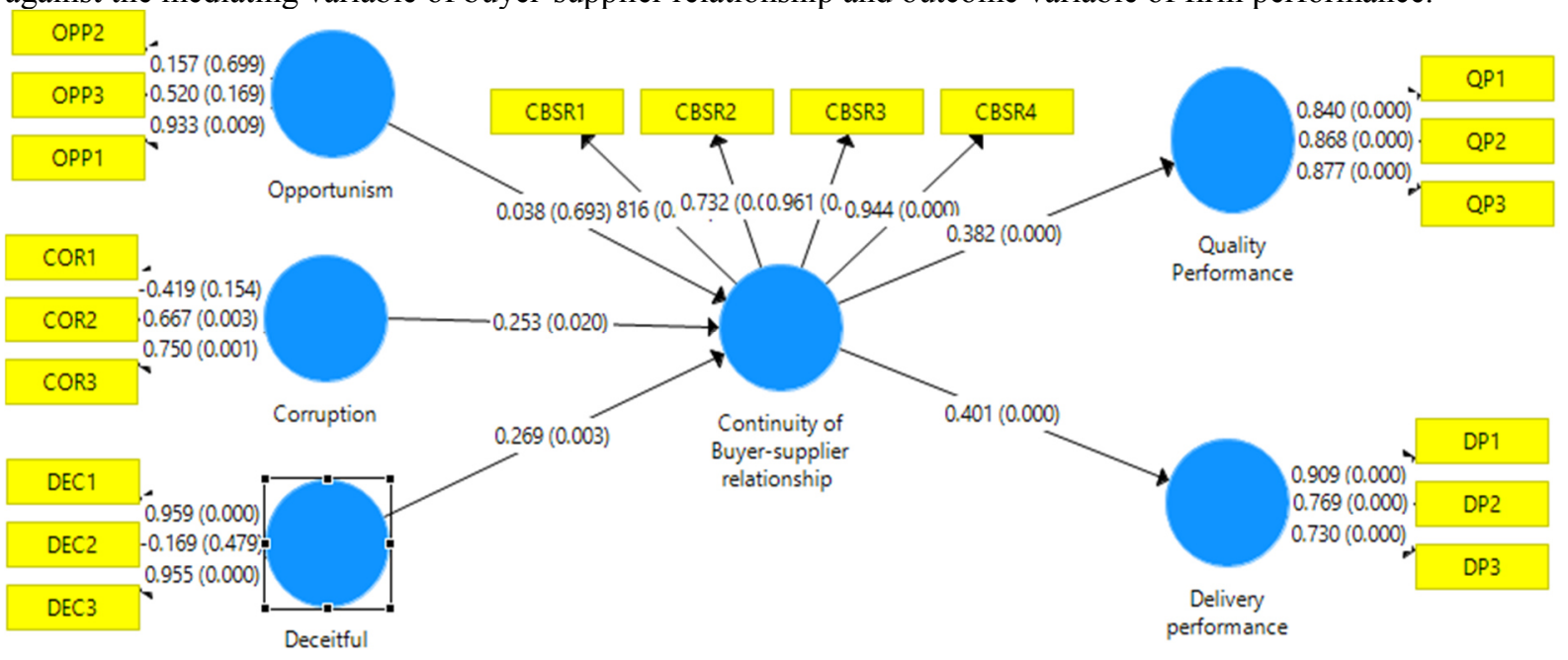

Fig. 2. SEM results

\subsection{Testing of hypotheses}

The PLS-based structural equation modeling technique was performed using Smart PLS 3.0 to determine the effects of supplier unethical practices on the continuity of buyer-supplier relationships, (b) the mediating effects of effects continuity of buyer-supplier relationships on firm performance. Path analysis results of the model are displayed in Table 3. Considering the direct relations included in our model, it has been determined that two factors of corruption $(\beta=0.253, p=0.020)$ and supplier's deceitful behaviors $(\beta=0.269, p=0.003)$ have significant and direct effects on the continuity of the buyer-supplier relationship while opportunism demonstrated no significant effects. Therefore, hypothesis $\mathrm{H} 3 \mathrm{~b}, \mathrm{H} 3 \mathrm{c}, \mathrm{H} 4 \mathrm{~b}$ and $\mathrm{H} 4 \mathrm{c}$ were supported. On the aspect of mediating effect, the model indicates that the continuity of the buyer-supplier relationship mediates the relationship between corruption, supplier's deceitful and firm performance (delivery and quality performance) as stipulate in Table 3 . Therefore, hypothesis $\mathrm{H} 3 \mathrm{~b}, \mathrm{H} 3 \mathrm{c}, \mathrm{H} 4 \mathrm{~b}$ and $\mathrm{H} 4 \mathrm{c}$ has been supported and reject $\mathrm{H} 2 \mathrm{a}$.

\section{Table2. Direct Effect}

\begin{tabular}{|l|c|c|c|c|}
\hline Relationship & $\boldsymbol{\beta}$-value & S.D & $\begin{array}{c}\text { t- } \\
\text { Statistics }\end{array}$ & $\begin{array}{l}\text { p- } \\
\text { Values }\end{array}$ \\
\hline $\begin{array}{l}\text { Continuity of Buyer-supplier relationship -> Delivery } \\
\text { performance }\end{array}$ & 0.401 & 0.057 & 7.019 & 0.000 \\
\hline $\begin{array}{l}\text { Continuity of Buyer-supplier relationship -> Quality } \\
\text { Performance }\end{array}$ & 0.382 & 0.078 & 4.916 & 0.000 \\
\hline Corruption -> Continuity of Buyer-supplier relationship & 0.253 & 0.108 & 2.335 & 0.020 \\
\hline Deceitful -> Continuity of Buyer-supplier relationship & 0.269 & 0.090 & 2.983 & 0.003 \\
\hline Opportunism -> Continuity of Buyer-supplier relationship & 0.038 & 0.097 & 0.394 & 0.693 \\
\hline
\end{tabular}


Table2. Indirect Effect

\begin{tabular}{|l|c|c|c|c|}
\hline & $\begin{array}{c}\boldsymbol{\beta}- \\
\text { value }\end{array}$ & S.D & $\begin{array}{c}\text { t- } \\
\text { statistics }\end{array}$ & $\begin{array}{c}\text { p- } \\
\text { values }\end{array}$ \\
\hline $\begin{array}{l}\text { Corruption -> Continuity of Buyer-supplier relationship -> Delivery } \\
\text { performance }\end{array}$ & 0.101 & 0.047 & 2.138 & 0.033 \\
\hline $\begin{array}{l}\text { Deceitful -> Continuity of Buyer-supplier relationship -> Delivery } \\
\text { performance }\end{array}$ & 0.108 & 0.041 & 2.620 & 0.009 \\
\hline $\begin{array}{l}\text { Opportunism -> Continuity of Buyer-supplier relationship -> Delivery } \\
\text { performance }\end{array}$ & 0.015 & 0.041 & 0.376 & 0.707 \\
\hline $\begin{array}{l}\text { Corruption -> Continuity of Buyer-supplier relationship -> Quality } \\
\text { Performance }\end{array}$ & 0.096 & 0.049 & 1.985 & 0.048 \\
\hline $\begin{array}{l}\text { Deceitful -> Continuity of Buyer-supplier relationship -> Quality } \\
\text { Performance }\end{array}$ & 0.103 & 0.045 & 2.290 & 0.022 \\
\hline $\begin{array}{l}\text { Opportunism -> Continuity of Buyer-supplier relationship -> Quality } \\
\text { Performance }\end{array}$ & 0.015 & 0.038 & 0.387 & 0.699 \\
\hline
\end{tabular}

\section{Discussion}

Based on the findings, the main antecedents of continuity of buyer-supplier relationship are supplier unethical practices and resultant consequences are quality and delivery performance. This study aims to make a contribution to the literature by proposing a model, for both practitioners and researchers of ethics supply chain. Therefore, the model that was tested using Tanzania environment explains that unethical behaviors of suppliers have huge impact to the continuity of relationships, and the continuity of buyer-supplier relationship mediate the effects between supplier deceitful and delivery performance as well quality performance. Similarly, the continuity of buyersupplier relationship mediates the effects between corruption practices and firm performance (Quality and delivery performance. In a nutshell, the study revealed that the antecedents of continuity relationship are supplier deceitful and corruption while the consequence is quality performance and delivery performance.

Opportunism is the aggressive selfishness and disregards the impact of the firm's actions on others (Hawkins et al., 2008). Opportunist behaviors of the supplier have no significant effect on the continuity of relationships. This is consistent to Luo et al. (2015) who get the same results in his study. One of the reasons for this may stem from the supplier's perceiving that opportunist behaviors are looking out for oneself. Another reason may arise from types of opportunism. Also Luo (2006) suggests, opportunism has been classified as a strong form and a weak form. It is very hard to observe weak form opportunism. Therefore, the relation between the opportunistic behavior and the continuity of relationship suggests alignment with the extant literature.

Deceitful unethical behavior has a direct effect on the continuity of relationships. Accordingly, if deceitful behavior increases, the continuity relations of the supply chain appear to be impossible to maintain. Carter (2000) points out that deceitful practices have significant effects on satisfaction. Additionally, he notes that those who tend to behave in a deceitful manner during their commercial relations will sooner or later pay the price. Hill et al. (2009) indicate that deceitful activities have a significant negative association with long-term relationships. Similarly, deceitful unethical behavior was found having indirect effect on firm performance. This is to say that, the practices do not only harm continuity buyer-supplier relationship but also it has consequences on quality and delivery performance. This results are in alignment with a number of past literatures (Bag et al., 2018).

Corruption is defined as a form of dishonesty or criminal offense undertaken by a supplier entrusted to work with organization, to acquire illicit benefit or abuse power for one's private gain. Corruption are common practices in procurement activities in Tanzania public entities (Sheng et al., 2018). The results indicated that corruption has direct influence on the continuity of buyer-supplier relationship as indirect effect on both quality and delivery performance. One can argue that, corruption practices undermine the continuity relationship because the practices in most of the time is performance by supplier with the involvement of some few unethical employees and when the organization identified the misconduct they normally terminate the contract and relationship with that supplier. The study findings are consisted with several past studies (Srinivasan et al., 2017).

\section{Conclusion}

In general, this study offers the theoretical and practical contributions to the field of supply chain. Furthermore, the study adds body of knowledge to the ethical supply chain literatures. Many studies have been focused on unethical behaviors especially on impact of ethical practices on buyer-supplier relationship. However, this study will bridge the gap by investigating the antecedents and consequences of supplier unethical practices. The major result of this study shows that supplier deceitful behaviors and corruption has both direct and indirect effect to the firm performance (quality and delivery performance). At the same time, the results suggest that the continuity of buyer-supplier relationship mediate the relationship between supplier unethical practices (Deceitful and corruption) with firm performance (quality and delivery). Finally, this study does not found any significant relationship 
between opportunity and continuity as well opportunism with quality and delivery performance the mediating role of continuity of buyer-supplier relationship.

\subsection{Limitations}

Our results provide important explanations of long-term outcomes of unethical behavior and continuity of buyersupplier relationship. Despite the contribution of this study, it has also some limitations which should be considered in future studies. One limitation of this study is, it has been conducted in developing country, which should be taken into consideration; and the fact that results can change according to the culture, economy and welfare levels of the societies should not be ignored. In addition, the study was conducted only in the public sector; accordingly, the design, analyses, results and interpretation of the research have been carried out by considering a single sector. The findings to be obtained as a result of the implementation of the study shall be beneficial for other sectors in terms of the elimination of certain problems.

\subsection{Further research}

This study was conducted in public sector, there is a great potential for future studies to be conducted in other sector to compare the findings of this study. In addition, this study was conducted using cross-section design. It well known that the aspect of ethical practices tends to change from time to time based on the factors such as strictness of leaders and effectiveness of the existing legislation. It will be imperative, if other studies could consider using longitudinal data to cutter the problem in this study and come up with justifiable results. In addition, measuring the effects of unethical behaviors on the reliance between the parties shall offer a new point of view. Future research should increase the sample size and broaden the geographic location to obtain larger data and also can be added the new constructs to conceptual model to improve generalization of the findings.

\section{Reference}

Ahamed, A. J., Stump, R. L., and Noboa, F. (2020), "What Drives Importer Opportunism? Learning from a Developing Country in Latin America”, Journal of Global Marketing, Vol.5 No.1, pp. 1-19.

Appolloni, A., and Nshombo, J. M. M. (2014), "Public procurement and corruption in Africa: a literature review", Public Procurement's Place in the World, Vol.3 No.8, pp. 185-208.

Bag, S., Gupta, S., and Telukdarie, A. (2018), "Exploring the relationship between unethical practices, buyersupplier relationships and green design for sustainability", International Journal of Sustainable Engineering, Vol. 11 No. 2, pp. 97-109.

Bendixen, M., and Abratt, R. (2007), "Corporate identity, ethics and reputation in supplier-buyer relationships", Journal of Business Ethics, Vol. 76 No. 1, pp. 69-82.

Carter, C. R. (2000), "Ethical issues in international buyer-supplier relationships: a dyadic examination", Journal of operations management, Vol. 18 No. 2, pp. 191-208.

Chen, J.-Y., and Baddam, S. R. (2015), "The effect of unethical behavior and learning on strategic supplier selection", International Journal of Production Economics, Vol. 167 No., pp. 74-87.

Chin, W. W., Thatcher, J. B., and Wright, R. T. (2012), "Assessing common method bias: Problems with the ULMC technique", MIS quarterly, Vol. No., pp. 1003-1019.

Corsten, D., Gruen, T., and Peyinghaus, M. (2011), "The effects of supplier-to-buyer identification on operational performance-An empirical investigation of inter-organizational identification in automotive relationships", Journal of Operations Management, Vol. 29 No. 6, pp. 549-560.

Das, T. (2005), "Deceitful behaviors of alliance partners: potential and prevention", Management Decision, Vol. No.

de Sousa Monteiro, M., Viana, F. L. E., and de Sousa-Filho, J. M. (2018), "Corruption and supply chain management toward the sustainable development goals era", Corporate Governance: The International Journal of Business in Society, Vol. No.

Fornell, C., and Larcker, D. F. (1981). Structural equation models with unobservable variables and measurement error: Algebra and statistics: Sage Publications Sage CA: Los Angeles, CA.

Gonzalez-Padron, T. L. (2016), "Ethics in the supply chain: Follow-up processes to audit results", Journal of Marketing Channels, Vol. 23 No. 1-2, pp. 22-33.

Hair, J., Black, W., Babin, B., Anderson, R., and Tatham, R. (2006), "Multivariate Data Analysis (6th Eds) Pearson Prentice Hall", New Jersey, Vol. No.

Hair, J. F., Ringle, C. M., and Sarstedt, M. (2013), "Partial least squares structural equation modeling: Rigorous applications, better results and higher acceptance", Long range planning, Vol. 46 No. 1-2, pp. 1-12.

Hair Jr, J. F., Sarstedt, M., Hopkins, L., and Kuppelwieser, V. G. (2014), "Partial least squares structural equation modeling (PLS-SEM)", European business review, Vol. No.

Hawkins, T. G., Wittmann, C. M., and Beyerlein, M. M. (2008), “Antecedents and consequences of opportunism in buyer-supplier relations: Research synthesis and new frontiers", Industrial Marketing Management, Vol. 
37 No. 8, pp. 895-909.

Hill, J. A., Eckerd, S., Wilson, D., and Greer, B. (2009), “The effect of unethical behavior on trust in a buyersupplier relationship: The mediating role of psychological contract violation", Journal of Operations Management, Vol. 27 No. 4, pp. 281-293.

Jamil, R., Mohammad, J., and Ramu, M. (2019), "Antecedents of unethical behaviour intention: Empirical study in public universities in Malaysian context", Journal of Academic Ethics, Vol. 17 No. 1, pp. 95-110.

Kaynak, R., Sert, T., Sert, G., and Akyuz, B. (2015), "Supply chain unethical behaviors and continuity of relationship: Using the PLS approach for testing moderation effects of inter-organizational justice", International Journal of Production Economics, Vol. 162 No., pp. 83-91.

Kline, R. B. (2015). "Principles and practice of structural equation modeling", Guilford publications.

Luo, Y. (2006), "Opportunism in Inter - firm Exchanges in Emerging Markets [1]", Management and Organization Review, Vol. 2 No. 1, pp. 121-147.

Luo, Y., Liu, Y., Yang, Q., Maksimov, V., and Hou, J. (2015), "Improving performance and reducing cost in buyer-supplier relationships: The role of justice in curtailing opportunism", Journal of Business Research, Vol. 68 No. 3, pp. 607-615.

Mazibuko, G., and Fourie, D. J. (2017), "Manifestation of unethical procurement practices in the South African public sector", African Journal of Public Affairs, Vol. 9 No. 9, pp. 106-117.

Millington, A., Eberhardt, M., and Wilkinson, B. (2005), "Gift giving, guanxi and illicit payments in buyersupplier relations in China: Analysing the experience of UK companies", Journal of business ethics, Vol. 57 No. 3, pp. 255-268.

Mugarura, J. T., Ntayi, D., and Muhwezi, D. (2010), "Buyer-supplier collaboration, adaptation, trust, commitment and relationship continuity of selected private manufacturing firms in Kampala", A masters dissertation,(Uganda): Makerere University Business School, Vol.9 No.12

Narain, R., and Singh, A. (2012), "Role of buyer-supplier relationship and trust in organizational performance", Delhi Business Review, Vol. 13 No. 2, pp. 73.

Ozkan-Tektas, O. (2014), "The effects of opportunism and trust on buyer-supplier relationship: Do commitment types matter", International Journal of Business and Social Research, Vol. 4 No. 9, pp. 14-26.

Rebernik, M., and Bradač, B. (2006), "Cooperation and opportunistic behaviour in transformational outsourcing", Kybernetes, Vol.3 No.7

Sarstedt, M., and Cheah, J.-H. (2019). Partial least squares structural equation modeling using SmartPLS: a software review: Springer.

Shamsollahi, A., Chmielewski-Raimondo, D. A., Bell, S. J., and Kachouie, R. (2020), "Buyer-supplier relationship dynamics: a systematic review", Journal of the Academy of Marketing Science, Vol. No., pp. 119.

Sheng, S., Zhou, K. Z., Li, J. J., and Guo, Z. (2018), "Institutions and opportunism in buyer-supplier exchanges: the moderated mediating effects of contractual and relational governance", Journal of the Academy of Marketing Science, Vol. 46 No. 6, pp. 1014-1031.

Skowronski, K., Benton Jr, W., and Hill, J. A. (2020), "Perceived supplier opportunism in outsourcing relationships in emerging economies", Journal of Operations Management, Vol. 66 No. 7-8, pp. 989-1023.

Srinivasan, R., Narayanan, S., and Narasimhan, R. (2017), "An investigation of justice, conflict, and moderating effects of supplier autonomy and cultural distance in buyer-supplier relationships", IEEE Transactions on Engineering Management, Vol. 65 No. 1, pp. 6-20.

Svensson, G., and Bååth, H. (2008), "Supply chain management ethics: conceptual framework and illustration", Supply Chain Management: An International Journal, Vol. No.

Tangpong, C., Hung, K.-T., and Ro, Y. K. (2010), "The interaction effect of relational norms and agent cooperativeness on opportunism in buyer-supplier relationships", Journal of Operations Management, Vol. 28 No. 5, pp. 398-414.

Wang, M., Zhang, Q., Wang, Y., and Sheng, S. (2016), "Governing local supplier opportunism in China: Moderating role of institutional forces", Journal of Operations Management, Vol. 46 No., pp. 84-94.

Wang, Q., Li, J. J., Ross, W. T., and Craighead, C. W. (2013), "The interplay of drivers and deterrents of opportunism in buyer-supplier relationships", Journal of the Academy of Marketing Science, Vol. 41 No. 1, pp. 111-131.

Wang, Z., Ye, F., and Tan, K. H. (2014), "Effects of managerial ties and trust on supply chain information sharing and supplier opportunism”, International Journal of Production Research, Vol. 52 No. 23, pp. 7046-7061.

Williamson, O. E. (1993), "Transaction cost economics and organization theory", Industrial and corporate change, Vol. 2 No. 2, pp. 107-156.

Wong, K. K.-K. (2013), "Partial least squares structural equation modeling (PLS-SEM) techniques using SmartPLS", Marketing Bulletin, Vol. 24 No. 1, pp. 1-32.

Yan, T., and Kull, T. J. (2015), "Supplier opportunism in buyer-supplier new product development: A China - 
US study of antecedents, consequences, and cultural/institutional contexts”, Decision Sciences, Vol. 46 No. 2, pp. 403-445.

Yun, G., Ebrahimpour, M., Bandyopadhyay, P., and Withers, B. (2019), “Internal and vendor employees' unethical behaviors in the supply chain: the case of India", Benchmarking: An International Journal, Vol. 6 No.3, pp. 13-25. 